\title{
Jewell Osterholm: Sharing Fifty Years of Insight
}

\section{Tony Anene-Maidoh, MS', Mitchell Maltenfort, $\mathrm{PhD}^{2}$}

'Jefferson Medical College, Thomas Jefferson University, Philadelphia, PA

${ }^{2}$ Department of Neurological Surgery, Thomas Jefferson University, Philadelphia, PA

\section{Sample of articles published in 1957}

\section{Twenty years of Leucotomy}

Freeman W. Proc R Soc Med. 1957 Feb; 50(2):79-84. Five-to-ten-year follow up of 162 cases of duodenal ulcer treated by vagotomy with and without associated gastric operations.

Walters W, Mobley JE. Ann Surg. 1957 May;145(5):753-7. The functional significance of the first thoracic ganglion in sympathectomy of the upper extremity in man.

Coldwater KB, Alexander WF, Cox JW, Randall WC. Ann Surg. 1957 Apr;145(4):530-9.

Jewell L. Osterholm was appointed Professor and Chairman of the Department of Neurosurgery in 1974, and left the Chairmanship in 1994. Recently, he gave a series of workshops on performing neurological examinations. These workshops are being archived on DVD so future residents can benefit from Dr. Osterholm's training. The emphasis is on interviewing and observing the patient; the only specialized devices used are the stethoscope and the reflex hammer.

Dr. Osterholm received his MD from Washington University School of Medicine in 1957, and his postgraduate training in neuropathology, neurology, and neurosurgery at the Montreal Neurologic Institute of McGill University. He came to Philadelphia in 1963, when he joined the neurosurgical service at Hahnemann Medical College; he became director of the Division of Neurological Surgery in 1967. He was responsible for the residency training program, spinal cord injury center, and neurosurgical research laboratories. He became chair of the Jefferson Department of Neurosurgery in 1974, as an experienced administrator with an active research program and a large surgical practice. By 1980, the Jefferson neurosurgical program provided more than 1,300 major neurosurgical operations yearly.

Residency training in both Neurosurgery and Neurology was enhanced in 1982, when an admitting arrangement was developed between these two departments to provide wider sharing of neurosurgical patients and a broader diagnostic workup. Neurosurgical residents received greater exposure to the basic neurosciences, neuroradiology, neuropathology, pediatric neurosurgery, and

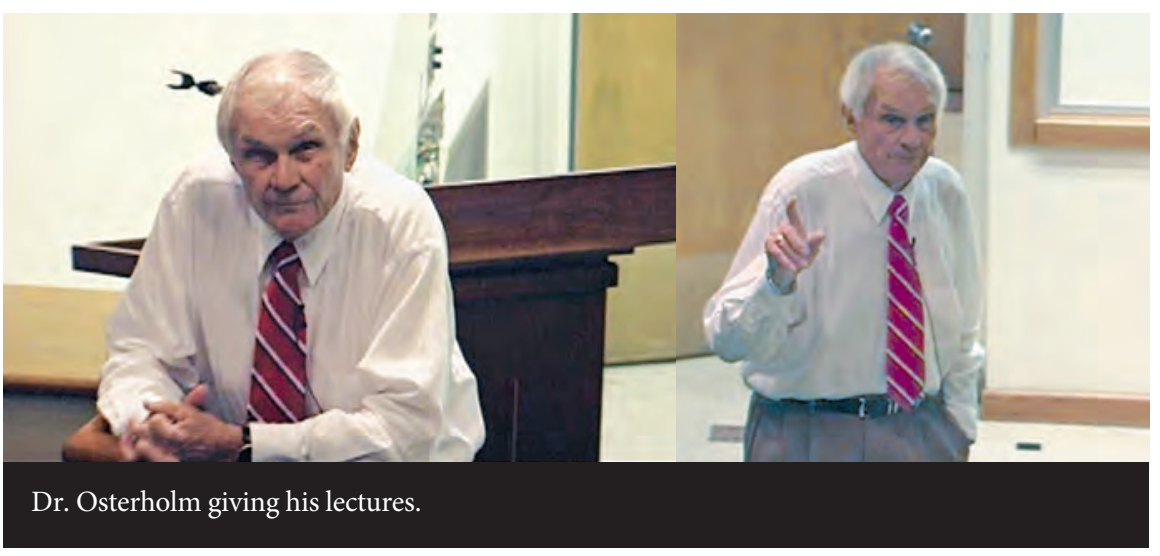

laboratory techniques. Resident attendance at various local and national conferences became routine. When asked about his star pupils Dr. Osterholm said "You can teach anyone to be a good neurosurgeon, but you need to be a natural with your hands to be great".

One of the biggest achievements during Dr. Osterholm's tenure was the establishment of the Regional Spinal Cord Injury Center of

"The first thing that goes in the press of a busy day is the neurological exam."

- Dr. Osterholm
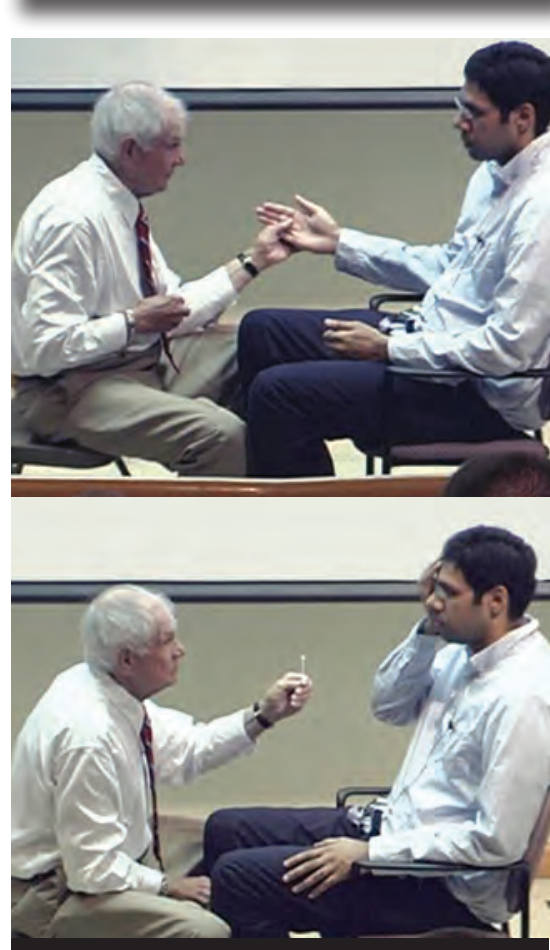

Dr. Osterholm performs a sample neurological exam on a resident (Dr. Sanjay Yadla) 
Delaware Valley at Jefferson under the aegis of the Department of Rehabilitation Medicine in conjunction with the Departments of Neurosurgery and Orthopedic Surgery.

An outstanding feature of the Osterholm years was the intense activity in laboratory research. In the early years, attention focused mainly on the various reactions (metabolic, vascular, neurochemical and electrophysiological) of the spinal cord to trauma. By the late 1970's, the research emphasis began to shift to the study of stroke and the relief of cerebral ischemia and cellular anoxia by extravascular hyperoxygenation through perfusion of the

\section{"If the sign says Open for}

Business we take anybody."

$$
\text { - Dr. Osterholm }
$$

third circulation with a balanced oxygenated fluorocarbon emulsion. This project eventually dominated the research program, was well funded, and had the most favorable progress. Nine United States patents related to the method were granted to Dr Osterholm in 1984.

While Dr. Osterholm was a medical student at Washington University School of Medicine he had planned to become a cardiothoracic surgeon, and in the last rotation of his fourth year he rotated through the Neurosurgery department, and then he decided to become a neurosurgeon. Dr. Henry Schwartz, Chairman of Neurosurgery at Washington University became his icon.

Dr. Osterholm stated that the operating microscope and new imaging modalities (MRI, $\mathrm{CT}$, etc.) were the most interesting technical improvements at the time he practiced. $\mathrm{He}$ noted that back then neurosurgeons did all their own diagnosis. Dr. Osterholm's favorite operation was trigeminal neuralgia, it was a rewarding procedure because it was a long lasting effective cure for patients experiencing immense unbearable pain. His least favorite operation was syringomyelia, the procedure did not resolve the condition and it seemed to always come back; as a result he did not do many of them in the later part of his career. When asked if he had any advice for neurosurgeons and people interested in the field, Dr. Osterholm said "It's a noble profession, do the right thing".

\section{Dr. Osterholm's Bibliography}

1. Caldwell FT, Jr., Osterholm JL, Sower ND, Moyer CA: Metabolic response to thermal trauma of normal and thyroprivic rats at three environmental temperatures. Ann Surg 150:976-988, 1959

2. Faust DS, Brady LW, Croll MN, Osterholm JL, Schaupp R: Evaluation of the use of regional oxygenation technics to enhance the localization of radioisotopes in tumors. Radiology 87:285-290, 1966

3. Osterholm JL, Lemmon WM, Hooker TB, Pyneson J: Electrorespiration by stimulation of thoracic spinal cord. Surg Forum 17:421-423, 1966.

4. Bansal S, Brady LW, Olsen A, Faust DS, Osterholm J, Kazem I: The treatment of metastatic spinal cord tumors. JAMA 202:686-688, 1967

5. Osterholm JL, Pyneson J: Television magnification in surgery. Technical note. J Neurosurg 26:442-446, 1967.

6. Osterholm JL, Hooker T, Pyneson J: Electrothoracic artificial respiration. J Neurosurg 28:298-304, 1968

7. Osterholm JL, Bell J, Meyer R, Pyenson J: Experimental effects of free serotonin on the brain and its relation to brain injury. 1. The neurological consequences of intracerebral serotonin injections.

8. Osterholm JL, Meyer R: Experimental effects of free serotonin on the brain and its relation to brain injury. 2. Traumainduced alterations in spinal fluid and brain. J Neurosurg 31:413-416, 1969.

9. Osterholm JL, Pyenson J: Experimental effects of free serotonin on the brain and its relation to brain injury. 3. Serotonin-induced cerebral edema. J Neurosurg 31:417-421, 1969.

10. Faust DS, Tatem HR, 3rd, Brady LW, Olsen AK, Osterholm JL, Kazem I, Mancall EL: Radiation therapy in the management of medulloblastoma. Neurology 20:519-522, 1970.

11. Mathews GJ, Ambruso VT, Osterholm JL: Hypothermic, hyperosmolar saline irrigation of cisterna magna: a new method for the relief of pain. Surg Forum 21:445-447, 1970.

12. Osterholm JL: Reaction of the cerebral venous sinus system to acute intracranial hypertension. J Neurosurg 32:654-659, 1970.

13. Heineman HS, Braude AI, Osterholm JL: Intracranial suppurative disease. Early presumptive diagnosis and successful treatment without surgery. JAMA 218:1542-1547, 1971

14. Mathews GJ, Osterholm JL: The small lumbar canal: a suggested classification. Trans Am Neurol Assoc 96:275278, 1971.

15. Osterholm JL, Mathews GJ: A proposed biochemical mechanism for traumatic spinal cord hemorrhagic necrosis. Successful therapy for severe injuries by metabolic blockade. Trans Am Neurol Assoc 96:187-191, 1971

16. Osterholm JL, Mathews GJ: Treatment of severe spinal cord injuries by biochemical norepinephrine manipulation. Surg Forum 22:415-417, 1971.

17. Osterholm JL, Mathews GJ, Irvin JD, Angelakos ET: A review of altered norepinephrine metabolism attending severe spinal injury: results of alpha methyl tyrosine treatment and preliminary histofluorescent studies. Proc Veterans Adm Spinal Cord Inj Conf 18:17-21, 1971.

18. Mathews GJ, Osterholm JL: Painful traumatic neuromas. Surg Clin North Am 52:1313-1324, 1972.

19. Osterholm JL, Mathews GJ: Altered norepinephrine metabolism following experimental spinal cord injury. 1. Relationship to hemorrhagic necrosis and post-wounding neurological deficits. J Neurosurg 36:386-394, 1972.

20. Osterholm JL, Mathews GJ: Altered norepinephrine metabolism, following experimental spinal cord injury. 2. Protection against traumatic spinal cord hemorrhagic necrosis by norepinephrine synthesis blockade with alpha methyl tyrosine. J Neurosurg 36:395-401, 1972.
21. Mathews GJ, Osterholm JL: Autonomic deafferentation rhizotomy for surgical relief of chronic neck and back pain. Surg Forum 24:442-444, 1973.

22. Mathews GJ, Zarro V, Osterholm JL: Cancer pain and its treatment. Semin Drug Treat 3:45-53, 1973.

23. Osterholm JL, Hill HF, Moberg RS, Ostdahl R: Improved environment for spinal cord regeneration by anti-catecholamine therapy (preliminary report). Proc Veterans Adm Spinal Cord Inj Conf:118-123, 1973.

24. Osterholm JL, Hirtz D, Hill HF: Successful treatment of severe experimental spinal cord injuries by intracisternal 3-alpha-dimethyltyrosine. Surg Forum 24:440-442, 1973.

25. Osterholm JL, Mathews GJ, Irvin JD, Calesnick B: Chapter 29. Anti-norepinephrine therapy against traumatic hemorrhagic necrosis of the spinal cord: preliminary report. Clin Neurosurg 20:382-399, 1973

26. Gonzales CF, Osterholm JL: The lack of renografin-76 toxicity in acute severe spinal cord injury. Radiology 112:605 $608,1974$.

27. Osterholm JL: Noradrenergic mediation of traumatic spinal cord autodestruction. Life Sci 14:1363-1384, 1974.

28. Osterholm JL: The pathophysiological response to spinal cord injury. The current status of related research. Neurosurg 40:5-33, 1974

29. Alderman JL, Osterholm JL, D'Amore BR, Moberg RS, Irvin JD: Influence of arterial blood pressure upon central hemorrhagic necrosis after severe spinal cord injury. Neurosurgery $4: 53-55,1979$.

30. Martinez LJ, Osterholm JL, Berry RG, Lee KF, Schatz NJ: Trans-sphenoidal removal of a Rathke's cleft cyst. Neurosurgery 4:63-65, 1979.

31. Alderman JL, Osterholm JL, D'Amore BR, Williams HD: Catecholamine alterations attending spinal cord injury: a reanalysis. Neurosurgery 6:412-417, 1980.

32. Alderman JL, Osterholm JL, D'Amore BR, Williams HD, Irvin JD: The influence of the adrenal glands upon acute spinal cord injury. Life Sci 26:1627-1632, 1980.

33. Martinez LJ, Alderman JL, Glaeser BS, Hare TA, Osterholm JL: Changes in the free amino acids of the injured spinal cord of the cat. Brain Res 182:237-241, 1980.

34. Martinez LJ, Alderman JL, Kagan RS, Osterholm JL: Spatia distribution of edema in the cat spinal cord after impact injury. Neurosurgery 8:450-453, 1981.

35. Bose B, Kraut W, Osterholm JL: Intracerebral hematoma: spontaneous cure by drainage into the middle ear. A case report. Neurosurgery 10:103-104, 1982

36. Smullens SN, Scotti DJ, Osterholm JL, Weiss AJ: Preoperative embolization of retroperitoneal hemangiopericytomas as an aid in their removal. Cancer 50:1870-1875, 1982.

37. Bose B, Myers DL, Osterholm JL: Arachnoiditis presenting as a cervical cord neoplasm: two case reports. Neurosurgery 12:120-122, 1983.

38. Bose B, Northrup B, Osterholm J: Giant basilar artery aneurysm presenting as a third ventricular tumor. Neurosurgery 13:699-702, 1983.

39. Jarrell BE, Posuniak E, Roberts J, Osterholm J, Cotler J, Ditunno J: A new method of management using the Kim-Ray Greenfield filter for deep venous thrombosis and pulmonary embolism in spinal cord injury. Surg Gynecol Obstet 157:316-320, 1983

40. Osterholm JL, Alderman JB, Triolo AJ, D'Amore BR, Williams HD, Frazer G: Severe cerebral ischemia treatmen by ventriculosubarachnoid perfusion with an oxygenated fluorocarbon emulsion. Neurosurgery 13:381-387, 1983.

41. Bose B, Northrup BE, Osterholm JL, Cotler JM, DiTunno JF: Reanalysis of central cervical cord injury management. Neurosurgery 15:367-372, 1984

42. Bose B, Osterholm JL, Berry R: A reproducible experimental model of focal cerebral ischemia in the cat. Brain Res 311:385-391, 1984 
43. Osterholm JL, Alderman JB, Triolo AJ, D’Amore BR, Williams HD: Oxygenated fluorocarbon nutrient solution in the treatment of experimental spinal cord injury. Neurosurgery 15:373-380, 1984.

44. Bose B, Huang P, Myers D, Osterholm J: Intrinsic third ventricular craniopharyngioma: two case reports with review of the literature. Del Med J 57:389-394, 1985.

45. Bose B, Northrup BE, Osterholm JL: Delayed vertebro-basilar insufficiency following cervical spine injury. Spine (Phila Pa 1976) 10:108-110, 1985

46. Bose B, Osterholm JL, Northrup BE, Cotler JM: Management of lumbar translocation injuries: case reports. Neurosurgery 17:958-961, 1985.

47. Bose B, Osterholm JL, Triolo A: Focal cerebral ischemia: reduction in size of infarcts by ventriculo-subarachnoid perfusion with fluorocarbon emulsion. Brain Res 328:223 231, 1985 .

48. Cotler HB, Cotler JM, Stoloff A, Cohn HE, Jerrell BE, Martinez L, Northrup BE, Osterholm JL, Rosato FE: The use of autografts for vertebral body replacement of the thoracic and lumbar spine. Spine (Phila Pa 1976) 10:748-756, 1985.

49. Mikaelian DO, Eyyunni U, Osterholm J, Fariello R, Jassal SP Hearing preservation in surgery for acoustic neuroma. Tran Pa Acad Ophthalmol Otolaryngol 37:255-258, 1985.

50. Bose B, Osterholm JL, Kalia M: Ganglioside-induced regeneration and reestablishment of axonal continuity in spinal cord-transected rats. Neurosci Lett 63:165-169, 1986.

51. Bose B, Osterholm JL, Payne JB, Chambers K: Preservation of neuronal function during prolonged focal cerebral ischemia by ventriculocisternal perfusion with oxygenated fluorocarbon emulsion. Neurosurgery 18:270-276, 1986.

52. Gonzalez CF, Osterholm JL, Triolo AJ, Bell RD, Menghetti RA: Fluorocarbon emulsion as a potential contrast medium in the subarachnoid space and brain tissue. Experiments in cats. Acta Radiol Suppl 369:554-557, 1986.

53. Sataloff RT, Bowman C, Baker SR, Osterholm J: Transfacial resection of intracranial tumor. Am J Otol 9:222-228, 1988.

54. Schaefer DM, Flanders A, Northrup BE, Doan HT, Osterholm JL: Magnetic resonance imaging of acute cervical spine trauma. Correlation with severity of neurologic injury. Spine (Phila Pa 1976) 14:1090-1095, 1989

55. Triolo AJ, Osterholm JL, Kratky MT: Enhancement of the Arthus reaction and suppression of delayed type hypersensitivity (DTH) by pluronic F-68, a detergen frequently used to prepare perfluorocarbon emulsions. Int J Immunopharmacol 11:241-248, 1989.

56. Buchanan LE, Ditunno JF, Jr., Osterholm JL, Cotler JM Staas WE, Jr.: Spinal cord injury: a ten-year report. Pa Med 93:36-39, 1990.

57. Triolo AJ, Osterholm JL, Alexander GM, Bell RD, Frazer GD: Local cerebral glucose metabolism after global ischemia: treatment by ventriculocisternal perfusion with a fluorocarbon emulsion. Neurosurgery 26:480-487; discussion 487-488, 1990

58. Bell RD, Frazer GD, Osterholm JL, Duckett SW: A novel treatment for ischemic intracranial hypertension in cats. Stroke 22:80-83, 1991.

59. Duckett S, Osterholm J, Schaefer D, Gonzales C, Schwartzman RJ: Ossified mucin-secreting choroid plexus adenoma: case report. Neurosurgery 29:130-132, 1991.

60. Duckett S, Schwartzman RJ, Osterholm J, Rorke LB, Friedman D, McLellan TL: Biopsy diagnosis of familial Alexander's disease. Pediatr Neurosurg 18:134-138, 1992.

61. McNulty SE, Weiss J, Azad SS, Schaefer DM, Osterholm JL, Seltzer JL: The effect of the prone position on venous pressure and blood loss during lumbar laminectomy. J Clin Anesth 4:220-225, 1992

62. Schaefer DM, Flanders AE, Osterholm JL, Northrup BE: Prognostic significance of magnetic resonance imaging in the acute phase of cervical spine injury. J Neurosurg 76:218223, 1992.
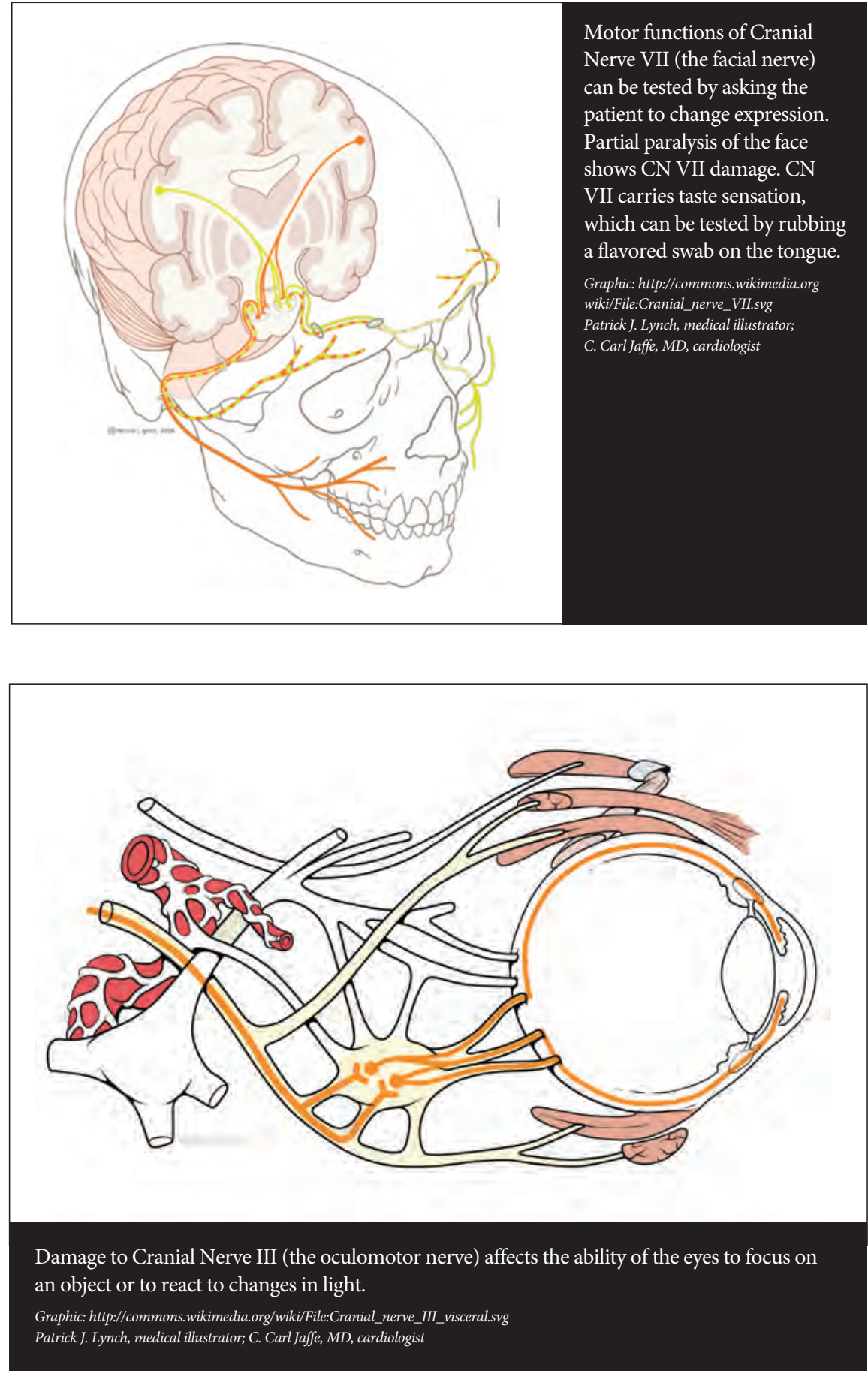